\title{
HPLC determination of encapsulated 5-fluorouracil in lyoiphilized liposomes
}

\author{
Irena Stojanovska1, Suzana Trajkovic-Jolevska2*, Aneta Dimitrovska²

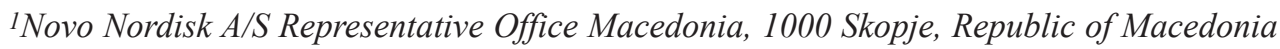 \\ ${ }^{2}$ Faculty of Pharmacy, Vodnjanska 17, 1000 Skopje, Republic of Macedonia
}

Received March 2003; accepted August 2003

\begin{abstract}
5-fluorouracil is used as an antineoplastic agent in the treatment of several malignant neoplasm, alone or in a combination with other antineoplastic drugs. Due to the difficulties in delivery of antineoplastic drugs on the target place, serious adverse events and hazardous effects, recent advanced researches are focused on the topical colloidal systems as drug carriers for the chemical substance. Colloidal drug carriers, as liposomes, can improve the therapeutic effects of the chemical substances by modifying their distribution and increasing their efficacy.

The aim of this study was to develop HPLC method for quantitative determination of encapsulated 5-fluorouracil in lyophilized liposomes.

HPLC method was developed using the following chromatographic conditions: column- LiChrospher ${ }^{\circledR}$ 60, RP Selected B, $125 \times 4 \mathrm{~mm}$, $5 \mu \mathrm{m}$; mobile phase - $0.02 \mathrm{M}$ phosphate buffer $\mathrm{pH} 4.7$; flow rate of $1.0 \mathrm{ml} / \mathrm{min}$; column temperature $20 \mathrm{eC}$; UV - detection at $266 \mathrm{~nm}$; injection volume - $20 \mu \mathrm{l}$. Linear relationship was obtained in the concentration range of $10-100 \mu \mathrm{g} / \mathrm{ml}, \mathrm{r}=0.9999$. Accuracy of the method was confirmed by standard addition method. Determination of encapsulated 5-fluorouracil in lyophilized liposomes was carried out with RSD of $0.71 \%$.

The proposed method could be used for rapid and precise quality control of lyophilized liposomes with 5-fluorouracil, used as drug delivery system, prepared for further incorporation in pharmaceutical dosage form-gel.
\end{abstract}

Key words: 5-fluorouracil, liposomes, quantitative determination, HPLC

\section{Introduction}

Existing scientific data show that from approximately 1000000 analysed chemical substances that are in a preclinical trial phase, performed in a scientific research and development institutions in the world, only one or two are with physic-chemical, pharmacological and safety characteristics, suitable for further development and modification with the final target of producing active substance with desired therapeutic effects (1). Having these facts as a background, most of the pharmaceutical companies are oriented to design a new pharmaceutical form, instead of research and design of new drug products. Targeting drugs today's through carrier system is a central theme of pharmaceutical development and accent is paid on the use of the existing potential resource of marketed and patented drug substances with known therapeutic effect and modification of their pharmaco-therapeutic characteristics (2). Improvement in their pharmaco-therapeutic characteristics is achieved with

\footnotetext{
*suzana.jolevska@baba.ff.ukim.edu.mk
}

tel. +3892126032 fax. +3892123054 decreasing/minimizing their side effects through chemical modification of drug substance and further incorporation in suitable drug system-carriers. Colloidal drug carriers as liposomes and nanoparticles can be used to improve the therapeutic characteristics of marketed and new drugs, by modifying their distribution and increasing their efficacy/safety and by reducing their system toxicity (3). Design of the liposome carrier concept in order to achieve a pharmaceutical level and development of liposomes as potential drug carrier for therapeutic agents took more than 2 decades (4). In recent years, liposomes are widely used as carrier systems for many drugs, including small molecular weight drugs, therapeutic proteins, chemotherapeutic agents, antigens, immunomodulators, chelating compounds, haemoglobin, diagnostic agents etc.

5 -fluorouracil is inactive, pyrimidine "prodrug", widely used as an antineoplastic agent in the treatment of common malignacies, in the form of injection, cream, topical solution, tablets etc. Due to the various side effects of 5-fuorouracil, use of liposomes as a drug delivery system gives a site-spe- 
cific delivery of the active substance and increased duration of action with increased therapeutic efficacy. Furthermore, incorporation of liposomes with 5-fluorouracil in pharmaceutical dosage form, for example gel, gives more comfortable way of administration to the patients (5).

The official monographs of 5-fluorouracil in USP XXIV and Ph. Eur. 2000, prescribe quantitative determination of 5-fluorouracil with titrimetry technique using 0.1 $\mathrm{N}$ tetrabutylammonium hydroxide in a presence of thymol blue as indicator solution $(6,7)$.

USP XXIV prescribed UV-spectrophotometric determination of 5-fluorouracil in injection, cream and topical solution at $266 \mathrm{~nm}$, using phosphate buffer $\mathrm{pH} 4.7$ as a solvent (6). Previous treatment of the samples for cream and topical solution included multiple extraction procedure using ethyl ether and chloroform.

Several methods based on high-performance liquid chromatography (HPLC) have been developed for assay of 5fluorouracil (8-10). Reported reversed-phase HPLC methods are used for quantitative determination of 5-fluorouracil in various material as serum, plasma and solid pharmaceutical dosage forms. Mobile phases used in these methods are $0.02-0.05 \mathrm{M}$ phosphate buffers $\mathrm{pH} 4.7$ and UV detection at $266 \mathrm{~nm}$. Ion pair HPLC method has been reported for the determination of 5-fluorouracil in human serum (11) using mobile phase, which was a combination of tetrabuthylammonium bromide, tetrabutylammonium hydrogen sulfate, methanol, sodium acetate and phosphate buffer and UV detection at $266 \mathrm{~nm}$. Another ion pair HPLC method was used for separation of 5-fluorouracil from its related substances uridin and uracil in plasma (12). The method employs the use of internal standard and organic extraction procedure. A sensitive reversed-phase HPLC method was developed for quantitative determination of 5-fluorouracil traces on vials (13). Mobile phase used in this method is $0.05 \%$ phosphoric acid $\mathrm{pH} 2.5$ and UV detection at $266 \mathrm{~nm}$.

The aim of our study was to develop HPLC method for quantitative determination of encapsulated 5-fluorouracil in lyophilised liposomes used as drug delivery system, formulated for further incorporation in pharmaceutical dosage form - gel.

\section{Experimental}

\section{Preparation of liposomes with 5-fluorouracil}

Liposome formulation containing 5-fluorouracil were prepared at the Institute of Pharmaceutical Technology at the Faculty of Pharmacy, Skopje, using film hydration technique (14). Optimized formula for the preparation of liposomes, which gives the highest $\%$ of encapsulation of 5 -fluorouracil of approximately $25 \%$ was used for the preparation of the sample (Phospholipon $90 \mathrm{H} /$ cholesterol $=15: 1$ and drug/aqueos phase $=1: 40)(15)$.
Lipid components were dissolved in chloroform and the solvent was evaporated under reduced pressure at $65^{\circ} \mathrm{C}$ until no chloroform odour could be detected in the vessel. An aqueous phase was prepared separately by dissolving 5-fluorouracil in phosphate buffer $\mathrm{pH}$ 7.4. Lipid film was hydrated with aqueous phase and unentrapted drug was removed by washing the liposomes with phosphate buffer pH 7.4 and ultracentrifugation $(25000 \mathrm{rpm}, 20 \mathrm{~min}$, three times). Phosphate buffer was used for reconstitution of pellets and for lyophilization.

Empty liposomes (without active substance 5-fluorouracil) were prepared in the same manner and same time as liposomes with 5-fluorouracil.

II Quantitative determination of encapsulated 5-fluorouracil in lyophilized liposomes

\section{Standard solution}

The stock standard solution with 5-fluorouracil ( $1 \mathrm{mg} / \mathrm{ml})$ was prepared in phosphate buffer $\mathrm{pH}$ 4.7. Standard solutions for the construction of the calibration curve (in the range of $10-100 \mu \mathrm{g} / \mathrm{ml}$ ) and working standard solution $(40 \mu \mathrm{g} / \mathrm{ml})$ were prepared with further appropriate dilutions with phosphate buffer $\mathrm{pH} 4.7$.

\section{Sample solution}

Quantity of lyophylized liposomes of approximately $0.8 \mathrm{~g}$ (accurately weighed) was transferred to the volumetric flask of $50 \mathrm{ml}, 20 \mathrm{ml}$ chloroform was added and the flask was placed in the ultrasonic bath for $15 \mathrm{~min}$, with slightly heating. After cooling at the room temperature, the flask was filled with phosphate buffer $\mathrm{pH} 4.7$ to the volume. The sample was centrifugated on $3000 \mathrm{rpm}$ for $25 \mathrm{~min}$. $1.0 \mathrm{ml}$ of the clear centrifugate was transferred to the volumetric flask of $10.0 \mathrm{ml}$ and filled with phosphate buffer $\mathrm{pH} 4.7$ to the volume.

Sample solution of empty lipsomes was prepared according to the same procedure.

All solutions were filtered through $0.45 \mu \mathrm{m}$ membrane filter, before injection.

\section{Apparatus}

A Waters HPLC equipped with Waters 600 E pump, Rheodyne 7725i manual injector and Photodiode Array Detector 996 was used. Column used was LiChrospher ${ }^{\circledR}$ 60, RP Selected B, $125 \times 4 \mathrm{~mm}, 5 \mu \mathrm{m}$. The mobile phase was $100 \% 0.02 \mathrm{M}$ phosphate buffer $\mathrm{pH}$ 4.7. Chromatographic condition set for this method was: flow rate $1.0 \mathrm{ml} / \mathrm{min}$; column temperature $20^{\circ} \mathrm{C}$; UV detection at $266 \mathrm{~nm}$; injection volume $20 \mu \mathrm{l}$.

\section{Results and Discussion}

Determination of the content of encapsulated 5-fluorouracil in lyophilized liposome formulation involves usage of organic solvent capable to destroy lipid structure, 
to release encapsulated 5-fluorouracil and to extract the released active substance in suitable solvent. 5-fluorouracil is sparingly soluble in water, slightly soluble in alcohol and practically insoluble in ethyl ether and chloroform. In the manufacturing procedure, chloroform was used as a solvent for the preparation of the lipid film. In the analytical procedure, chloroform was also used as a solvent for lyophilized liposomes and the extraction of the released 5-fluorouracil was carried out with phosphate buffer $\mathrm{pH}$ 4.7. Phosphate buffer $\mathrm{pH} 4.7$ was suitable solvent because it was used as mobile phase as well.

Under the proposed chromatographic conditions, the retention time of approximately $2.4 \mathrm{~min}$ for 5 -fluorouracil was obtained. The chromatograms of standard solution (a), empty liposome sample solution (b) and liposome sample solution (c) are presented in Fig. 1.

Linear relationship over the concentration range of $10-100 \mu \mathrm{g} / \mathrm{ml}$ of 5 -fluorouracil was obtained. The calibration curve was constructed by the results obtained for the peak areas versus concentration. The linear regression equation obtained by a least-squares method was $\mathrm{y}=1.0517+0.3392 c ; \mathrm{r}=0.9999$.

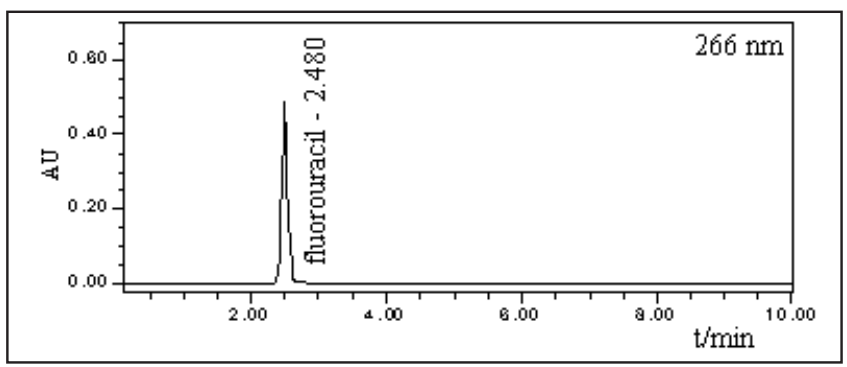

Fig. 1a. Chromatogram of standard solution of 5-fluorouracil $(40 \mu \mathrm{g} / \mathrm{ml})$

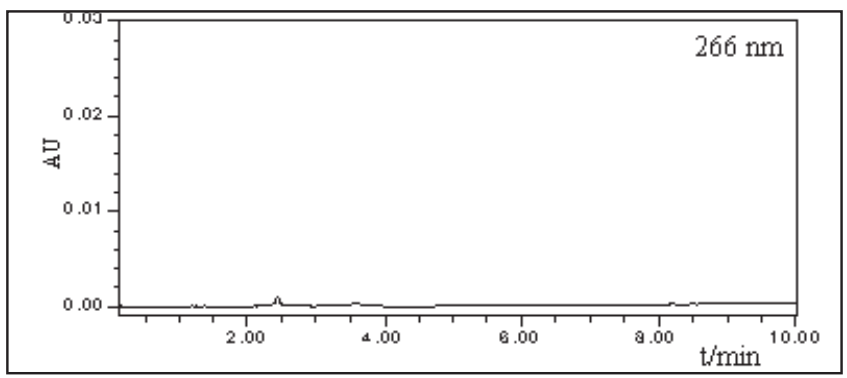

Fig.1b. Chromatogram of the empty liposomes solution

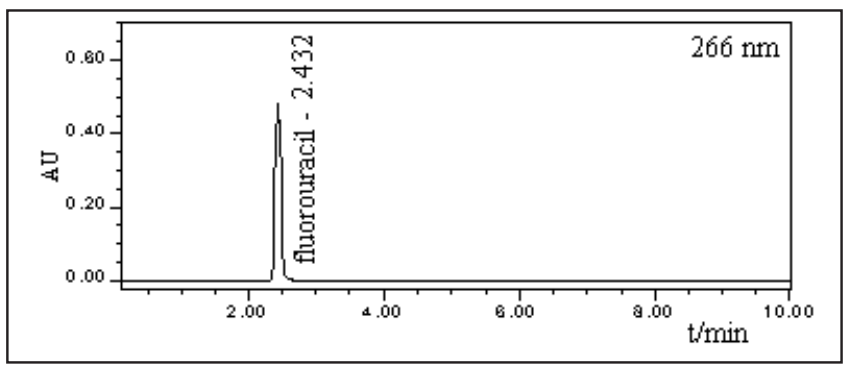

Fig. 1c. Chromatogram of the sample solution of 5-fluorouracil (40 mg/ml)
Precision of the method was confirmed by determination of:

- Repeatability of the system with 6 successive injection of standard solutions at working concentration with RSD value $0.22 \%$ and

- Repeatability of the method with 6 successive injections of sample solutions at working concentration with RSD value $0.71 \%$.

The results of the determination of encapsulated 5-fluorouracil in a lyophilized liposomes are presented in Table 1.

Table 1. Results of the determination of encapsulated 5-fluorouracil in lyophilized liposomes*

\begin{tabular}{cccc}
\hline \hline $\begin{array}{c}\text { Measured } \\
\mathrm{mg} / \mathrm{g}^{*}\end{array}$ & $\begin{array}{c}\text { Encapsulated } \\
\mathrm{mg} / \mathrm{g}^{*}\end{array}$ & $\begin{array}{c}\mathrm{SD} \\
\mathrm{mg} / \mathrm{g}^{*}\end{array}$ & $\begin{array}{c}\mathrm{RSD} \\
\%\end{array}$ \\
\hline 100 & 25.47 & 0.18 & 0.71 \\
\hline
\end{tabular}

*prepared according to the optimized formula (15) using film hydration method: drug/lipid phase $=1: 3.2 ;$ drug/aqueous phase $=1: 40$

The results obtained have shown that the encapsulated amount of 5-fluorouracil in a lyophilized liposomes prepared with the lipid film hydration technique is $25.47 \%$. These results are in accordance with the latest literature reported data indicating that the highest $\%$ of encapsulation of active substance in liposomes prepared according to this technique is up to $30 \%$ (14).

Accuracy of the method was confirmed by the standard addition method performed by adding 5-fluorouracil standard solution in amount of 50, 75 and $100 \%$ over the determined encapsulated content in lyophilized liposomes and results are shown in Table 2.

Table 2. Results of 5-fluorouracil determination in lyophlized liposomes by standard addition method*

\begin{tabular}{ccccc}
\hline \hline $\begin{array}{c}\text { Encapsulated } \\
\mathrm{mg} / \mathrm{g}^{*}\end{array}$ & $\begin{array}{c}\text { Added } \\
\mathrm{mg} / \mathrm{g}^{*}\end{array}$ & $\begin{array}{c}\text { Calculated } \\
\mathrm{mg} / \mathrm{g}^{*}\end{array}$ & $\begin{array}{c}\text { Determined } \\
\mathrm{mg} / \mathrm{g}^{*}\end{array}$ & $\begin{array}{c}\text { Recovery } \\
\%\end{array}$ \\
\hline & 12.00 & 37.47 & 37.17 & 99.22 \\
25.47 & 18.00 & 43.47 & 42.05 & 96.74 \\
& 24.00 & 49.47 & 48.18 & 97.40 \\
\hline
\end{tabular}

drug/lipid phase $=1: 3.2 ;$ drug/aqueous phase $=1: 40$

The obtained recovery values of $96.74-98.22 \%$ indicated that the proposed method is quantitative and accurate.

Detection limit and quantification limit were determined with the method based on the calibration curve studied using samples containing an analyte in the range of approximate $\mathrm{DL}$ and QL. The obtained values for DL and QL were $0.24 \mu \mathrm{g} / \mathrm{ml}$ and $0.78 \mu \mathrm{g} / \mathrm{ml}$, respectively. 


\section{Conclusion}

A simple and rapid reversed-phase HPLC method for quantitative determination of 5-fluorouracil in lyophilized liposomes was developed. The proposed method is precise, accurate and reproducible. The content of encapsulated 5-fluorouracil in lyophilized liposomes determined by the proposed HPLC method was found to be $25.47 \%$ which is in accordance with the reports in the literature indicating maximum $30 \%$ encapsulation of active component in liposomes using lipid film hydration technique for their preparation (14).

The method could be also used for determination of the active substance in the pharmaceutical dosage forms (gel) prepared with incorporation of 5-fluorouracil loaded liposomes, as well as in-process quality control of a previous prepared intermediate product (liposome dispersion).

\section{References}

1. J.R. Andersen., Guidelines for Management of Discovery Projects, NN Project Manual, Copenhagen, July 2000

2. S.Vemuri and C.T. Rhodes, a review, Pharm. Acta Helv. 70, 95-111, (1995).

3. G.M.Barrat, Pharmaceutical Science and Technology Today 3, 163-171, (2000).
4. D.J.A. Crommelin, G. Storm, Pharmaceutical Science and Technology Today 1, 19-31, (1998).

5. R.H.Williams, J.D.Wilson and D.W. Foster (Editors) Willaim's Textbook of Endocrinology, 7-th Ed., W.B. Saunders, Philadelphia, 1995

6. United States Pharmacopoeia XXIV, United Pharmacopeial Convection, Inc., Twinbrook Parkway, Rockville, 2000

7. European Pharmacopoeia, $4^{\text {th }}$, Council of Europe, Strasbourg, Supplement 2000

8. E.J. Quebbeman, J. Liquid Chro. 7, 1489-1494 (1984).

9. C.L. Hornbeck, R.A. Floyd, J.C. Griffith and J.E. Byfield, J. Pharm.Sci., 70, 1163-1166, (1981).

10. CromCircle, Merck Applications, Merck KgaA Darmstadt Germany, (1998).

11. M.W. De Gregorio and W.M. Holleran, Anal. letters 18(B1), 51-55, (1985).

12. G.J. Peters and I.Kraal, J. Chromatography 307, 464-468, (1984).

13. J. Delporte, P. Chenoix and Ph. Hubert, Science 5 ( 3), 119-121, (1999).

14. A. Chonn and P.R. Cullis, Curr. Opin. Biotechnol. 6, 698-708, (1995).

15. M.G. Dodov, Liposomes as biodegradabile carriers of 5-FUformulation and characterization, MSc thesis. University of "Ss Cyril and Methodius", Faculty of Pharmacy, Skopje 2002.

16. E.G.C.Clarke, Clark's Isolation and Identification of drugs, $2^{\text {nd }}$ Ed., The Pharmaceutical Press, London, 1986

\title{
Резиме
}

\section{HPLC определување на енкапсулиран 5-флуороурацил во лиофилизирани раствори}

\author{
Ирена Стојановска¹, Сузана Трајковиќ-Јолевска², Анета Димитровска²

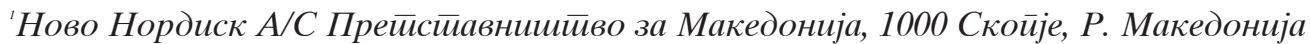

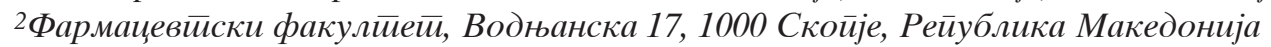

Клучни зборови: 5-флуороурацил, липозоми, квантитативно определување, HPLC

5-флуороурацил се употребува како антинеопластичен агенс при лекување на повеќе малигни неоплазми, сам или во комбинација со други антинеопластични лекови. Поради потешкотиите во испорачувањето до целното место, како и поради многуте несакани дејства на антинеопластичните лекови, најновите истражувања се однесуваат на употребата на колоидни системи како носители за активната супстанција. Колоидни носители, како липозомите, можат да го подобрат терапевтскиот ефект на хемиските супстанции преку модификување на нивната дистрибуција и зголемување на терапевтската ефикасност.

Целта на овој труд беше да се разработи HPLC метод за квантитативно определување на енкапсулиран 5-флуороурацил во лиофилизирани липозоми. Разработен е HPLC метод со употреба на реверзно фазна колона LiChrospher ${ }^{\circledR}$

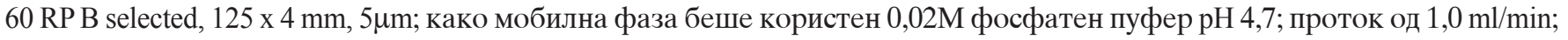
температура на колона $20^{\circ} \mathrm{C}$; UV-детекција на $266 \mathrm{~nm}$ и волумен на инјектирање $20 \mu \mathrm{l}$. Линеарноста на методот беше испитана и утврдена во опсегот на концентрации од 10-100 $\mu \mathrm{g} / \mathrm{ml}, \mathrm{r}=0,9990$. Точноста на методот беше потврдена со методот на стандардни додатоци. Содржината на енкапсулиран 5-флуороурацил во лиофолизираните липозоми беше определена со вредност на RSD од $0,71 \%$.

Предложениот HPLC метод може да биде употребен за брза и прецизна контрола на квалитет на лиофилизирани липозоми со 5-флуороурацил, како систем за испорака на лековита супстанција, подготвени за понатамошно вградување во дозиран фармацевтски облик-гел. 